\title{
SOUTH AFRICA'S D-DAY VETERANS
}

Cdr W.M. Bisset

SA Naval Museum, Simon's Town

Although some 657 members of the South African Union Defence Forces served in North West Europe between D-Day on 6 June 1944 and VE-Day on 8 May 1945, it would seem that relatively few of them were present on D-Day. South Africa's main contributions to the war effort were made in Ethiopia, Madagascar, the Western Desert, Italy and on her own home front which included the vital Cape Sea Route.

In volume two of his biography of General Smuts', Sir Keith Hancock has written: "The Cape of Good Hope lived up to its name and assumed once again its historic primacy in oceanic strategy. Without the Cape route, the Commonwealth could hardly have survived the War; without the Commonwealth, the Russians and Americans could hardly have won it".

In addition to those who served in the Union Defence Forces there were many South Africans who were serving in the British or Commonwealth forces or who joined up where they were on the outbreak of war. Since their serv- ice records are not readily available it is not possible to compile a definitive article on this topic at this stage. Even the records of our own personnel seconded to the British forces seldom reveal whether the servicemen concerned served on D-Day or not.

South Africans were present at Dunkirk and Dieppe so it was fitting that they should return to France when the tide turned.

The South African naval officers and ratings in the invasion fleet were the largest group of South African servicemen present on 6 June

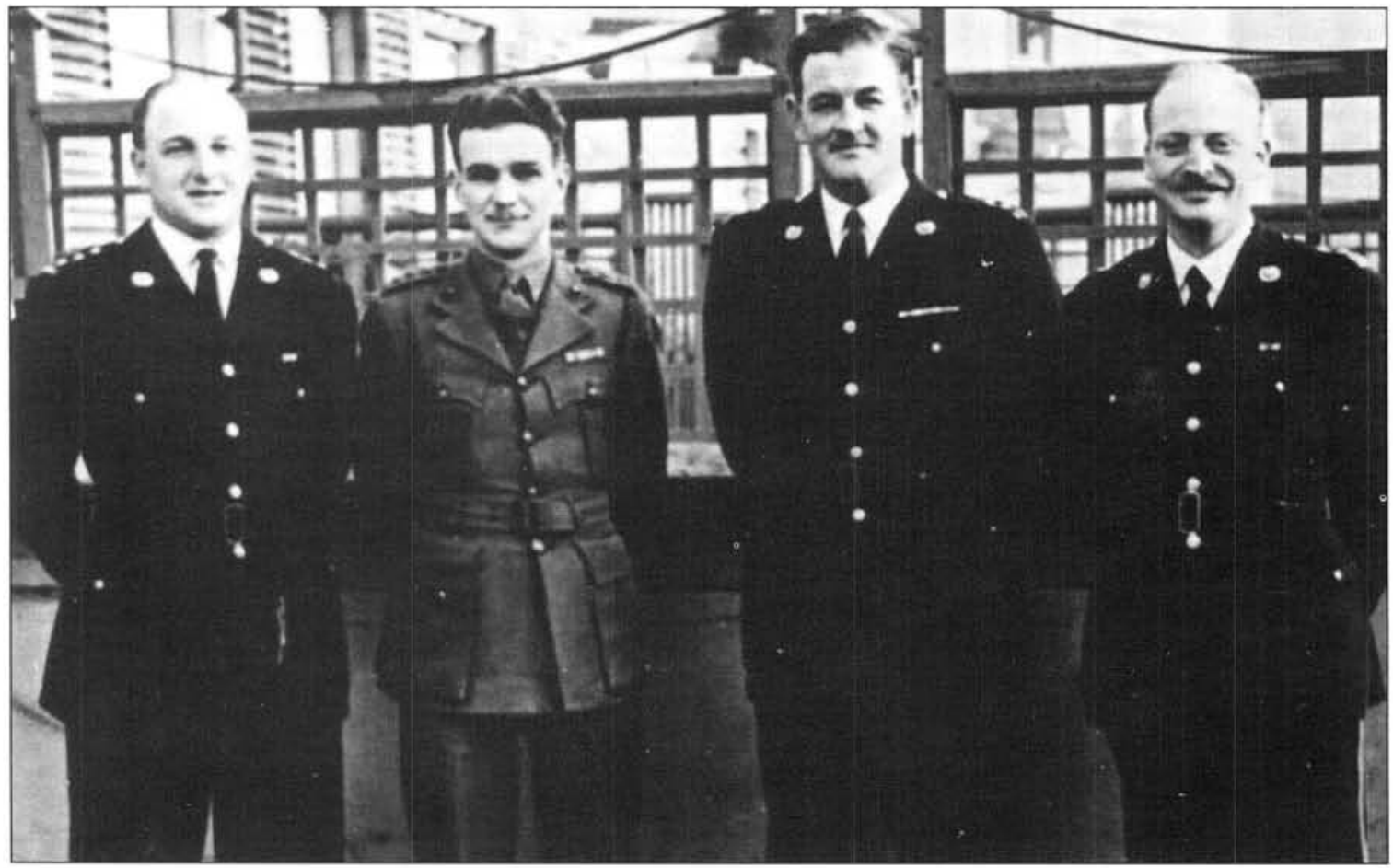

Four of the South Africans seconded to the Royal Marines.

Left to right : Captain E.B.Norton, Captain L.L.A. McKay, MC, Lieutenant C.K. Brown, MC, and Lieutenant T.Atkins in London in 1944. 
1944. Lieutenant Royston Davis Turnbull who had served in the Royal Naval Volunteer Reserve in Cape Town before the war was awarded the Distinguished Service Cross. His citation reads:

"This officer showed a magnificent example to his Flotilla when very heavily opposed whilst landing the 2nd Battalion United States Rangers near Vierville. Seeing three of his craft stranded on the beach and being subjected to intense mortar and machine-gun fire, he returned to their help. His hard work before the operation and his courage and leadership in the assault was an inspiration to all".

Sub-Lieutenant Bryan Powell, another seconded South African, was navigator in the newly commissioned Hunt Class destroyer, HMS STEVENSTONE, and was mentioned in despatches. HMS STEVENSTONE and a French destroyer were the first ships to follow the minesweepers into the invasion area off Juno Beach. HMS STEVENSTONE fired about 500 rounds at two German shore batteries before the landing craft went in. Enemy shells straddled the ship which was not hit because the gunners were Poles whose sympathies lay with the Allies.

By 20 h00 the barrels of the guns of HMS STEVENSTONE were worn out and only one round of unexpended anti-aircraft ammunition remained on board.

Another seconded South African naval officer present on D-Day was Lieutenant Dennis R. Stephens who had been awarded the Distinguished Service Cross for gallantry, daring and skill in the combined attack on Dieppe on 19 August 1942.

Lieutenant Stephens commanded the 2nd Landing Craft Flotilla on D-Day. In order to conserve fuel the flotilla was towed to France by Tank Landing Craft. There was a heavy flowing sea which caused frequent jerks in the smaller landing craft.

When the flotilla reached Juno Beach it took charge of the Duplex Drive tanks in the LCTs and guided them ashore. They were so low in the water that it was very difficult for the tank commanders to see where they were going. The flotilla then provided a smoke screen for the ships in the anchorage which were bom- barding the coast batteries. Lieutenant Stephens was later mentioned in despatches for clearing the approaches to Le Havre of moored mines. Another seconded South African, Lieutenant W.G. Payne from Durban, served ashore on Juno Beach where he was a Beach Master.

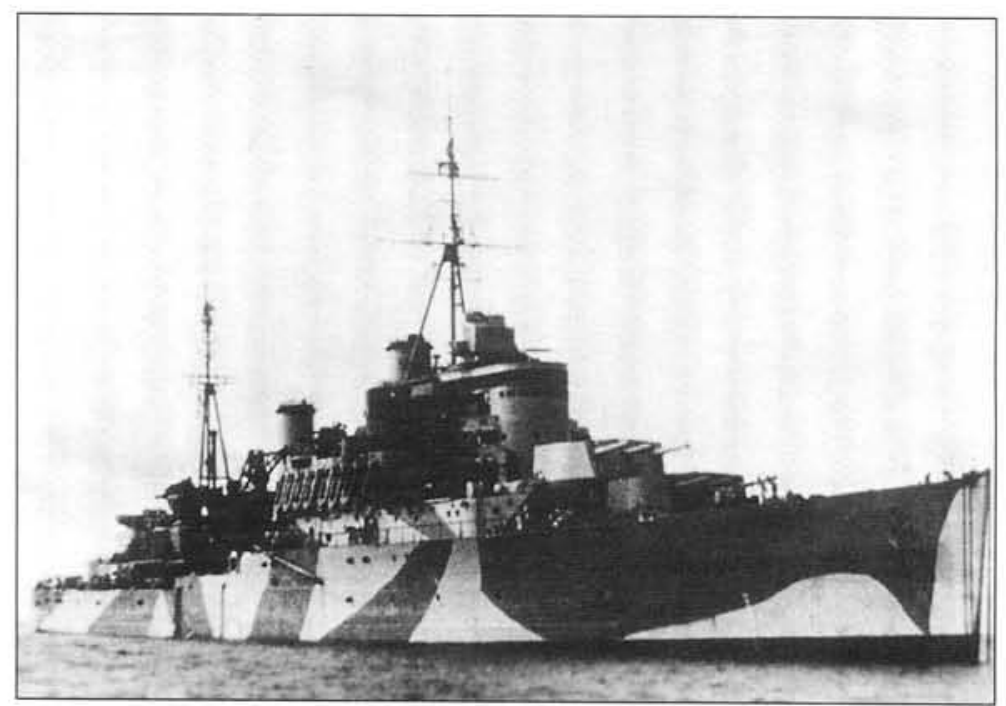

HMS MAURITIUS.

Three more members of the South African Naval Forces were mentioned in despatches on D-Day. Lieutenant (later Lieutenant Commander) C.J. van Heerden received his award for good service whilst serving in HMS FROBISHER (a Hawkins Class cruiser) in the maintenance of the small craft during the invasion of Normandy. Lieutenant J.W. Armstrong was mentioned for "gallantry, skill, determination and undaunted devotion to duty". Chief Petty Officer S.R. Reabow received his D-Day mention whilst serving in the Fiji Class cruiser HMS MAURITIUS.

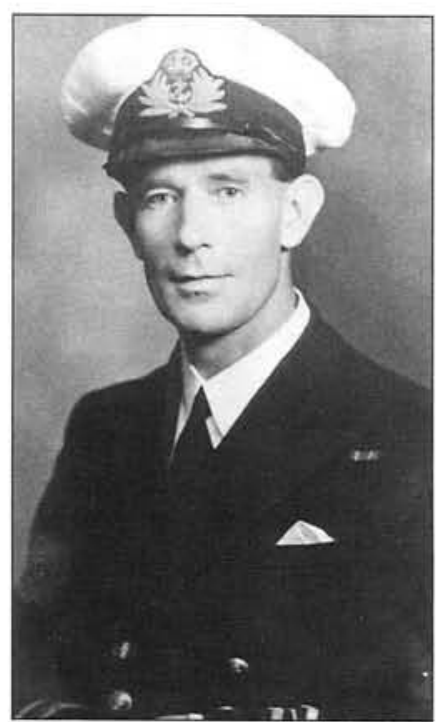

Lieutenant Commander $R$. Paterson, VRD. 
Sub-Lieutenant J.E. Ramsay of Durban in ML 465 was one of the first to cross the Channel. Able Seaman J. Barkley who served in the small Landing Ship Infantry, HMS PRINCE CHARLES, was killed in action on D-Day.

There can be no doubt that the most remarkable South African naval contingent present on D-Day was that serving in the Dido Class cruiser HMS SIRIUS. In October 1944 one officer, Sub Lieutenant C.T. Gordon and twenty one SANF ratings were serving in this ship. They took part in the landings at Algiers, Oran, Sicily, Salerno, Anzio, Normandy and the South of France.

Lieutenant-Commander Russel Paterson who was Commanding Officer of the RNVR base at Port Elizabeth from 1935 to 1941 commanded the Algerine Class minesweeper HMS PLUCKY on D-Day.

In March 1944 HMS PLUCKY was transferred to the Nore Command and based at Harwich. In April the 7th Flotilla left for Portsmouth to prepare for the invasion of Normandy - Operation Neptune - as part of Force J. HMS PELORUS (nOw SAS PIETERMARITZBURG) was the 7th Flotilla leader with the Senior Officer, Commander George Nelson, on board. The ships of the 7th Minesweeping Flotilla were the first in the Portsmouth and Solent area to sail. Commander Nelson made the signal "Nelson in the Van" as they rendezvoused to the south of St Catherine's Point on the Isle of Wight. This position became known as Picadilly Circus. The flotilla of nine ships and two danlayers set off for an area off Ouistreham in Seine Bay twenty miles south west of Le Havre. The flotilla then swept an area as an anchorage for other ships, dropped anchor at $03 \mathrm{hOO}$ and waited for the landing craft. After the assault the flotilla kept the area between channels No 7 and No 8 clear.

On 7 January 1944 the Adjutant-General approved the secondment of twenty six South African Army officers to the Royal Marines with effect from 27 December 1943. The Senior Officer, Captain L.L.A. McKay, recalls that the group was screened and selected by a Colonel in the Royal Marines from Alexandria and that they were drafted to the Portsmouth Division of the Royal Marines and after a period of orientation they were drafted to Royal Marine units.

Those with gunnery experience were drafted to the RM Armoured Support Group which took part in the initial landings on D-Day. The remainder were drafted to the RM Commandos and Landing Craft. More South African officers were seconded to the Royal Marines subsequently and all of them served in Normandy during the initial assault or later operations. A number of them also served in the Far East.

Two South Africans seconded to the Royal Marines were awarded the Military Cross for gallantry on D-Day. Their citations provide graphic details of their gallantry:

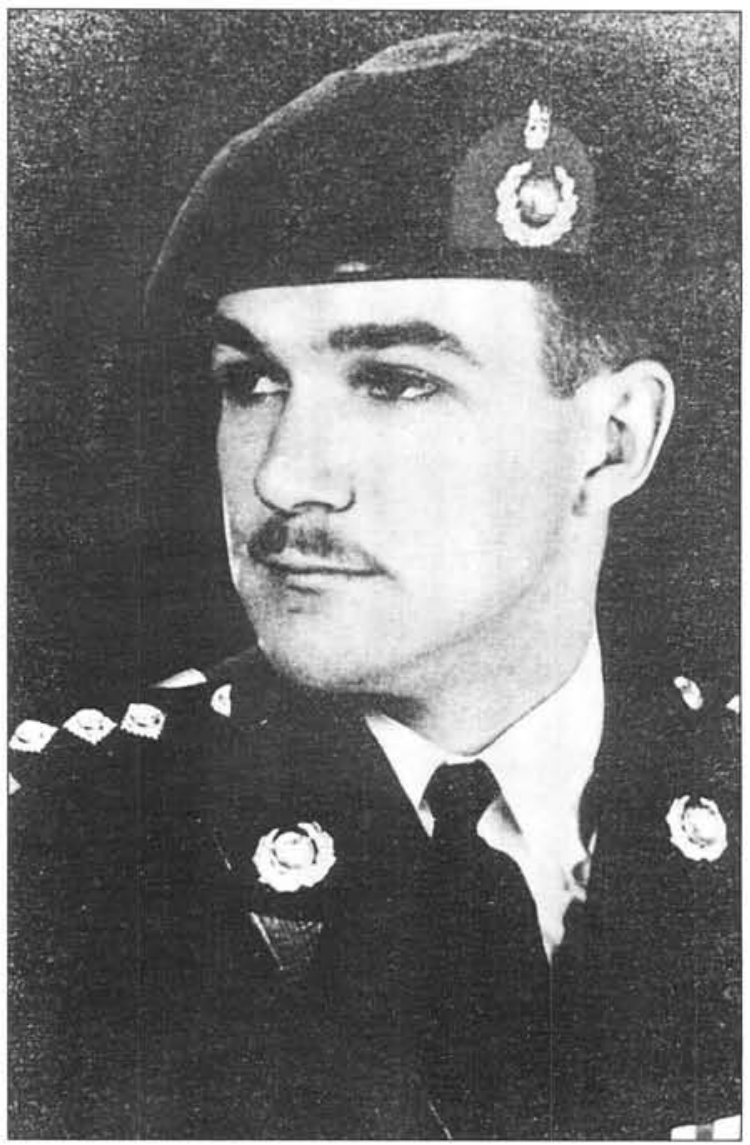

Captain L.L.A. McKay, MC.

Captain Lyle Louwrens Archibald McKay, South African Forces (attached Royal Marines).

"Captain McKay showed qualities of initiative, energy and courage in a high degree by spotting and engaging enemy strong points, machine gun positions and anti-tank guns from the beach throughout D-Day. In the course of the day he was wounded by a direct hit from a 75 millimetre shell which put the main armament of his Sherman tank out of action, but he nevertheless continued to engage the enemy with his .300 Browning machine gun until he finally moved inland from the beach with only one of four Centaur tanks, the remaining three still being out of action through damage to tracks on landing."

Lieutenant (temporary) Cecil Arthur Douglas Bircher, South African Forces (attached Royal Marines). 
"Lieutenant Bircher was Officer Commanding Troops in a LCT(A) carrying part of his troop. The craft engines broke down and it was towed from a position off the Isle of Wight to the assault area by a LCT and a LCl. On 6th June 1944 when approaching the beach at Bernieres-sur-Mer these craft had to cast off the LCT(A) which was left drifting sideways in a strong tide about 150 yards from the beach. Although there was a heavy sea running and the beach was still under close range fire, Lieutenant Bircher, without hesitation plunged into the water and swam about 100 yards to the shore with the beach lines. On arrival on the beach he secured the lines to some stakes, enabling his craft to beach, and disembarked his section of Centaur tanks. He subsequently led his section from the Canadian Sector in which he had landed into the sector of the 50th (N) Division to which he was attached although enemy opposition still persisted between the two sectors. Throughout the operation Lieutenant Bircher showed personal courage of the highest order and unflinching determination in the most adverse conditions to get his guns into action at the right time and place."

There can be no doubt that the best known South African airman to fly over the Normandy beaches was Group Captain A.G. 'Sailor' Malan, DSO and bar, DFC and bar, who was commanding No 20 Fighter Wing.

Major Arthur Clarence Rowe, a South African Air Force officer seconded to the RAF and serving in 196 Squadron RAF, was awarded the Distinguished Flying Cross. His citation reads:
"Major Rowe has completed many sorties which have included paratroop dropping, glider towing and bombing missions. He has also taken part in three major airborne operations, including Normandy and Arnhem. On many occasions his aircraft was hit by anti-aircraft fire whilst flying at low level. This did not deter Major Rowe who has, at all times, shown courage, cheerfulness and devotion to duty."

Some one hundred and fourteen South African Army officers seconded to the British Army qualified for the France and Germany Star. Many of them were decorated for gallantry.

Captain Roy Anderson from Johannesburg who had served in the 1st SA Light Tank Company in East Africa and Ethiopia served in the Royal Artillery of 30 Corps on D-Day.

Lieutenant Leonard Patrick Hurley of Queenstown joined the SA Tank Corps on 4 November 1940 and served in the Middle East where he was seconded to the Royal Armoured Corps. $\mathrm{He}$ served with the 4th City of London Yeomanry in Italy and Normandy and was present on D-Day. He was taken prisoner on 13 June 1944 and spent the rest of the war in a prisoner of war camp in Germany.

As has been shown above a number of South Africans served with distinction on D-Day. It is very likely that many more were present and that some of them were also decorated and it is hoped that their details will be traced in due course. South Africa recalls with pride the unflinching gallantry of her servicemen on D-Day and her part in liberating North West Europe in the months that followed.

\section{SOME OF THE SHIPS IN WHICH SECONDED SOUTH AFRICAN NAVAL PERSONNEL SERVED ON D-DAY}

\section{SHIP}

HMS AFFLECK

HMS AGGESSIVE

HMS ARGONAUT

HMS BLANKNEY

HMS BULOLO

HMS COPRA

HMS COTSWOLD

HMS DURBAN

HMS EMERALD
TYPE AND CLASS

\section{NUMBER OF OFFICERS AND}

RATINGS TRACED
Captain class frigate

Coastal Forces Base at Newhaven

Dido class cruiser

Hunt class destroyer

Landing ship Headquarters (large)

Combined Operations Base in Scotland

Hunt class destroyer

'D' class destroyer

'E' class destroyer
1

1

1

1

1

2

1

1

4 
SHIP

TYPE AND CLASS

NUMBER OF OFFICERS AND

RATINGS TRACED

SS EMPIRE ROSALIND

HMS EREBUS

HMS FAULKNOR

HMS FROBISHER

HMS GLASGOW

HMS GOODALL

HMS HAWKINS

HMS HORNET

HMS MALAYA

HMS MANTIS

HMS MAURITIUS

HMS MOUNSEY

HM ML 465

MULBERRY

HMS NARCISSUS

HMS ODYSSEY

HMS ORION

HMS PLUCKY

HMS POOLE

HMS PRINCE CHARLES

HMS RAMILLIES

HMS ROYALIST

HMS SCORPION

SS SHEAF CROWN

HMS SIRIUS

HMS STEVENSTONE

HMS WALDEGRAVE

HMS WALKER

HMS WHIMBREL

HMS WREN
Erebus class monitor

'F' class destroyer

Hawkins class destroyer

Southampton class destroyer

Captain class frigate

Hawkins class cruiser

Coastal Forces Base at Gosport

Queen Elizabeth class battleship

Insect class river gunboat

Fiji class cruiser

Captain class frigate

Fairmile 'B' motor launch

Flower class corvette

Base ship, London (Beach Assault Party)

Leander class cruiser

Algerine class minesweeper

Bangor class minesweeper

Landing ship infantry (small)

Royal Sovereign class battleship

Improved Dido class cruiser

'S' class destroyer

Dido class cruiser

Hunt class destroyer

Captain class frigate

'W' class destroyer

Black Swan class sloop

Black Swan class sloop
3

3

2

4

1

1

3

1

1

1

1

1

1

1

1

1

1

1

1

1

1

1

1

1

8

1

1

1

1

1

TOTAL 